\title{
COMPARATIVE MINERALOGICAL AND PETROGRAPHIC ANALYSIS OF PRIMARY KAOLINES WITHIN THE GLUKHIVETSKO-TURBIVSKIY AREA (PODILSKYY BLOCK OF THE UKRAINIAN SHIELD) \\ G.O. Slyusarenko
}

\section{ПОРІВНЯЛЬНИЙ МІНЕРАЛОГО-ПЕТРОГРАФІЧНИЙ АНАЛІЗ ПЕРВИННИХ КАОЛІНІВ ГЛУХІВЕЦЬКО-ТУРБІВСЬКОГО РАЙОНУ (ПОДІЛЬСЬКИЙ БЛОК УКРАЇНСЬКОГО ЩИТА) Г.О. Слюсаренко}

\begin{abstract}
The chemical transformation and mineral formation in weathering crust profile (from initial disintegration zone to kaolinite zone) are described. Depending on parental rocks the comparative characteristics of primary kaoline types is shown. Main parental rocks minerals and their transformations on various weathering stages are characterized. Together with comparison of quality of primary Zhezheliv kaoline (Zhezhelivske deposit) with the same of kaoline from other deposits of the GluchivetskoTurbivskiy area, general sources of harmful admixtures are also noted.

Key words: primary kaoline, weathering crust, mineralogical peculiarities.
\end{abstract}

Описуються мінералогічні та хімічні перетворення кори вивітрювання Глуховецько-Турбівського каолінового району. Наводиться порівняльна характеристика різновидів первинних каолінів в залежності від вихідних порід. Характеризуються головні породоутворюючі мінерали материнських порід та їх перетворення на різних стадіях вивітрювання. Порівнюється якість первинного каоліну Жежелівського родовища з таким інших родовищ Глухівецько-Турбівського району.

Ключові слова: первинні каоліни, кора вивітрювання, мінералогічні особливості.

Родовища та перспективні рудопрояви каоліну в Україні локалізовані переважно в межах Українського щита (УЩ) та його схилів. Тут розвинуті як первинні каоліни, що приурочені до кори вивітрювання (КВ) кристалічних порід докембрію, так і вторинні, перевідкладені.

Попит на каолін щороку стрімко зростає і на теперішній час задовольняється лише на $70 \%$. Якщо Україна до 1993 р. виробляла понад 1 млн т збагаченого каоліну і входила до лідируючої групи, то на цей час обсяг виробництва в країні скоротився до 170-200 тис. т [2]. Виробництво вищих марок каоліну потребує використання сучасного обладнання та новітніх технологій, яких країні на теперішній час бракує.

Район досліджень розташований в північно-західній частині УЩ у північній частині Подільського блока. Безпосередньо до нього примикає Волинський блок по субширотній Андрушівській зоні розломів. Подільський блок розділений Хмільницьким розломом на блоки другого порядку з істотно різною геологічною будовою - Вінницький («фемічний») і Бердичівський («салічний») [4]. Останній, у свою чергу, розчленовується на Іванопільський і Козятинський блоки третього порядку по Глухівецькому і Білопільському розломах. На півночі Вінницького блока розташований блок III порядку Літинський. Численними розривними порушеннями регіонального і локального характеру територія розбита на багато дрібніших фрагментів.

В межах Подільського блока УЩ розміщений Глуховецько-Турбівський каоліновий район, до якого віднесені Великогадомське, Глухівське, Жежелівське, Турбівське, Чубинське, Гуринське, Туча-Миколаївське та інші родовища, що містять половину розвіданих запасів первинних каолінів України.

На сьогодні детально вивчено стратиграфію регіону, петрографію, петрологію та генезис гранітоїдів і осадових комплексів, розглянуто геологічну будова Подільського блока УЩ $[1,5-7,9,15]$. Упродовж багатьох років науковці вивчали докембрійські утворення Верхнього Побужжя, їх вік та тектонічну будову. Найважливіше значення мають праці Ю.І. Половинкіної [7], О. І. Слензака [9], Е.Б. Наливкіної [6], В.М. Венедиктова [1]. Вивченню геохронології гранітоїдів присвячена робота М.П. Щербака [12], який встановив ранньопротерозойський вік чудново-бердичівських гранітів та гранатбіотитових гнейсів, що асоціюють з ними. В.А. Рябенко [8] багато публікацій присвятив вивченню тектоніки докембрію Верхнього Побужжя. Л.С. Сонкін [10] та Д.С. Гурський [2] протягом тривалого часу вивчали КВ та пов'язані з ними родовища каоліну. Вони детально дослідили Глухівецько-Турбівський каоліновий район. Територія досліджень покрита гравіметричною зйомкою (масштабу 1:200 000 та 
1:50 000), аеромагнітною зйомкою (масштабу 1:25 000) та електророзвідкою методом БЕЗ (у масштабі 1:100 000). Проте високий рівень вивченості району не сприяв, на жаль, формуванню єдиної точки зору на його геологічну будову, а послідовність становлення різних формацій, характер їх контактів, природа структур ще не з'ясовані і залишаються дискусійними.

Отже, незважаючи на тривалість вивчення представленої території Ущ, ще й досі залишаються перспективи щодо відкриття в межах Глухівецько-Турбівського каолінового району нових покладів каолінів. Отже, актуальною є проблема довивчення території родовищ та удосконалення технології видобування каолінів.

Власні мінералогічні та петрографічні дослідження каолінів проводились на Жежелівському родовищі. Якість каолінів та їх фізико-хімічні властивості, що визначають область можливого використання, залежать перш за все від мінерально-петрографічного складу та структурно-текстурних особливостей первинних порід, а також від ступеня та глибини їх переробки.

Для визначення форм знаходження оксидів заліза й титану в збагаченому каоліні Жежелівського родовища та характеру взаємозв'язку зі структурою каолініту були проведені дослідження в Київському національному університеті (аналітик Ю.Л. Гасанов). Проби каолінового концентрату вивчалися за методикою, що передбачала ї гранулометричний аналіз, виділення матеріалу фракцій 50-10, 10-5, 5-2 і менше 2 мкм у кількості, достатній для рентген-дифрактометричного фазового аналізу й визначення концентрацій $\mathrm{TiO}_{2}, \mathrm{Fe}_{2} \mathrm{O}_{3}$ та інших петрогенних оксидів методом рентген-флуоресцентного аналізу. Аналітичні дослідження виконувалися на приладах ДРОН-УМ1 і СРМ-25.

Найтиповішим представником родовищ первинних каолінів у межах Глухівецько-Турбівського каолінового району є Жежелівське родовище [10], яке має складну геологічну будову як кристалічного фундаменту, так і власне КВ. Воно знаходиться в межах тектонічно порушеної зони контакту різних за віком кристалічних комплексів, що відрізняються походженням, мінеральним складом і текстурноструктурними особливостями.

Поклади первинного каоліну Жежелівського родовища залягають на первинних лужних каолінах, які є перехідними різновидами від нормальних каолінів до каолініт-гідрослюдистих порід [11]. Вони складають нижню частину КВ та характеризуються наявністю в них реліктів зерен польових шпатів. Потужність лужних каолінів сягає до 10 м.

На заході Жежелівського родовища в нижній частині каолінової товщі були виявлені пеліканіти потужністю від 3,6 до 13,5 м. Пеліканіти - це продукти заміщення польових шпатів опал-каолінітовою сумішшю. Вони спостерігаються у вигляді невеликих, складної форми тіл, що просторово тяжіють до зон дезінтеграції або гідрослюд. Макроскопічно це білі чи світло-сірі міцні породи, іноді з реліктовою структурою субстрату. Встановлені тріщини в пеліканіті виповнюються також опалом.

Вважається [14], що первинні каоліни Жежелівського родовища утворилися за рахунок вивітрювання кристалічних порід в процесі повного розкладу алюмосилікатів (плагіоклазів, калієвого польового шпату та біотиту). Найбільш поширені серед материнських порід родовища є бердичівські граніти та їх мігматити, які контактують із супракрустальними товщами дністровсько-бузької серії та містять ксеноліти біотитових і гранат-біотитових гнейсів [3] .

КВ кристалічних порід у районі Жежелівського родовища широко розповсюджена, і їі потужність досягає понад 100 м. При цьому максимальні значення потужності КВ встановлені вздовж зон глибинних розломів та в місцях їх перетину з розломами різного рангу. Значною мірою потужність КВ контролюється палеорельєфом. Первинні каоліни перекриваються осадовими відкладами четвертинної та неогенової систем (табл. 1).

Мінералогічно первинні каоліни Жежелівського родовища представлені каолінітом (від 47 до 71\%) і кварцом (від 24 до 48\%). Різко підпорядковане значення у складі глинистої породи мають польові шпати (1-3\%), біотит (0,5-2\%), а також рудні ільменіт і лейкоксен (0,5-2\%).

У межах Жежелівського родовища на підставі досліджень були виділені три основних різновиди первинних каолінів.

1. Каоліни, які утворились по гранат-біотитових середньо-дрібнозернистих гранітах бердичівського комплексу нижнього протерозою та їх мігматитах (табл. 2). Цей різновид широко розповсюджений в межах родовища, потужність його досягає 18 м. Каоліни, що утворилися по бердичівським гранітах характеризуються реліктовою смугастою текстурою і строкатим забарвленням від світло-кремового і сірувато-білого з жовтими плямами до вохристо-жовтого й бурого, або концен- 
Таблиця 1. Усереднений геологічний розріз Жежелівського родовища

\begin{tabular}{|c|c|c|c|}
\hline \multirow{2}{*}{ Різновиди порід } & \multirow{2}{*}{$\begin{array}{c}\text { Геологічний } \\
\text { індекс }\end{array}$} & \multicolumn{2}{|c|}{ Потужність порід, м } \\
\hline & & від & до \\
\hline Грунтово-рослинний шар & $\mathrm{eQ}_{\mathrm{IV}}$ & 0,0 & 1,6 \\
\hline Суглинок бурий, до темно-бурого, масивний & $\mathrm{vdQ}_{\mathrm{IV}}$ & 0,0 & 1,9 \\
\hline Глина сіра, до темно-сірої, місцями піщана, з домішками каолініту & $\mathrm{edQ}_{\mathrm{I}}$ & 0,0 & 1,3 \\
\hline $\begin{array}{l}\text { Глина строката, щільна, різною мірою піщана, місцями } 3 \\
\text { прошарками каоліну }\end{array}$ & $\mathrm{N}_{1} \mathrm{st}$ & 0,0 & 1,9 \\
\hline К аолін вторинний перевідкладений & $\mathrm{N}_{1}$ & 0,0 & 1,9 \\
\hline К аолін нормальний & $\mathrm{Kz}-\mathrm{Mz}$ & 2,8 & 28 \\
\hline Каолін лужний & $\mathrm{Kz}=\mathrm{Mz}$ & 0,0 & 10,0 \\
\hline Каолінізована дресва, інтенсивно каолінізовані кристалічні породи & $\mathrm{K} z \mathrm{Mz}$ & $\begin{array}{r}\mathrm{M}_{2} \\
\text { пробур }\end{array}$ & Бно \\
\hline
\end{tabular}

труються у вигляді скупчень вздовж певних напрямків, що збігаються із смугастістю. Остання пов'язана з чергуванням гранітної та гнейсової складових вихідної породи.

\section{Таблиця 2. Мінеральний склад каоліну-сирцю Жежелівського родовища залежно від складу материнських порід}

\begin{tabular}{|c|l|c|c|c|c|c|}
\hline \multirow{2}{*}{$\begin{array}{c}\text { № } \\
\text { п/п }\end{array}$} & \multicolumn{1}{|c|}{ Різновиди первинних каолінів } & \multicolumn{3}{|c|}{ В міст мінералів у масових відсотках (від- до),\% } \\
\cline { 3 - 7 } & \multicolumn{1}{|c|}{ Кварц } & Каолініт & $\begin{array}{c}\text { Польовий } \\
\text { шпат }\end{array}$ & Біотит & $\begin{array}{c}\text { Ільменіт, } \\
\text { лейкоксен }\end{array}$ \\
\hline 1 & $\begin{array}{l}\text { за бердичівськими гранітами та їх } \\
\text { мігматитами }\end{array}$ & $27-48$ & $47-69$ & $1-2$ & $1-2$ & $0,5-1$ \\
\hline 2 & за середньозернистими гранітами & $26-37$ & $59-61$ & $1-3$ & до 1 & $0,5-1$ \\
\hline 3 & за гнейсами & $24-27$ & $69-71$ & $1-3$ & $0,5-1$ & до 1 \\
\hline
\end{tabular}

2. Каоліни, які утворились по середньо-крупнозернистих та апліт-пегматоїдних гранітах, в окремих випадках по пегматитах (табл. 2). Для них характерний світло-сірий до білого колір та наявність зерен кварцу розміром від 1 мм до 2-5 см. Каоліни, що утворились за пегматоїдними жилами і прожилками, містять залишковий кварц. Потужність такого різновиду каоліну сягає в окремих випадках $15,9 \mathrm{M}$.

3. Каоліни, які утворились по гнейсах, що містяться у вигляді прошарків серед каолінів по гранітах (табл. 2). Колір каоліну сірий, світло-сірий або кремовий, а у нижній частині покладу набуває зеленувато-сірого забарвлення, є безкварцовою або з незначним вмістом кварцу, масною на дотик пластичною тонколускуватою породою, потужність якої досягає 10,1 м.

Мінералого-петрографічні дослідження показали, що одним із найбільш поширених породоутворюючих мінералів, що входить до складу всіх материнських порід, є плагіоклаз, представлений альбіт-олігоклазом. Плагіоклаз - найменш стійкий до процесів вивітрювання, інтенсивно розкладається, швидко заміщуючись каолінітом без будь-яких проміжних мінеральних новоутворень. При цьому процес перетворення та заміщення відбувається вже на ранніх стадіях вивітрювання, в зоні початкового розкладу й дезінтеграції. Вивітрювання плагіоклазу у цій зоні супроводжується зміною валового хімічного складу породи, пов'язаною з різким зменшенням вмісту $\mathrm{Na}+\mathrm{Ta}^{\mathrm{Ca}}{ }_{2}+$.

Схема заміщення польових шпатів каолінітом виглядає таким чином:

$$
2 \mathrm{~K}\left[\mathrm{AlSi}_{3} \mathrm{O}_{8}\right]+2 \mathrm{H}_{2} \mathrm{O}+\mathrm{CO}_{2}=\mathrm{Al}_{2}(\mathrm{OH})_{4}\left[\mathrm{Si}_{2} \mathrm{O}_{5}\right]+4 \mathrm{SiO}_{2}+\mathrm{K}_{2} \mathrm{CO}_{3}[10] \text {. }
$$

За такою ж схемою відбувається гідроліз і заміщення каолінітом інших алюмосилікатів. Процес супроводжується повним або частковим винесенням окремих елементів, при цьому катіони $\mathrm{K}^{+}, \mathrm{Na}^{+}$, $\mathrm{Ca}^{2+}$, які утворюють при взаємодії з вуглекислотою легкорозчинні солі, переносяться підземними та поверхневими водами на значні відстані. Кремнезем при розкладі первинних мінералів частково витискається вуглекислотою і в розчиненому вигляді виноситься, але більша його частина переходить у колоїдний стан і за певних обставин випадає на місці у вигляді опалу. 
Другим з головних породоутворюючих мінералів є мікроклін, який стійкіший до вивітрювання; його кристали майже не змінюються на ранніх стадіях вивітрювання. Процес утворення глинистих мінералів відбувається повільно з наростанням ступеня інтенсивності вивітрювання. Каолінізація розвивається на окремих локальних ділянках кристалів мікрокліну, який перетворюється на каолініт лише в зоні повної каолінізації.

Біотит є основним носієм заліза в кислих породах Жежелівського родовища. Вивітрювання біотиту призводить до утворення, поряд із вторинними алюмосилікатами, мінералів вільних оксидів заліза, які присутні у тонкодисперсному та розсіяному станах. В зоні початкового розкладу та дезінтеграції біотит не зазнає жодних структурних змін, процеси вивітрювання проявляються лише у верхній частині зони початкової каолінізації. Початкові ознаки гідратації біотиту зводяться до підвищеної здатності розшаровуватись по площинах спайності та за зміною кольору. Перетворення біотиту в каолініт супроводжується нагромадженням дисперсного рудного мінералу, переважно гетиту, на місці руйнації та заміщення слюди.

Гранати в бердичівських комплексах представлені альмандином. Їх перетворення розпочинається в зоні часткової каолінізації, супроводжується утворенням пухкої маси, що складається з гідрослюди, гетиту та каолініту, і в результаті призводить до значного збагачення порід оксидами заліза.

Первинні каоліни Жежелівського родовища містять домішок заліза і титану, головним джерелом надходження яких є залізо- і титанвмісні мінерали материнських порід (рутил, сфен, ільменіт, гранат та біотит), а також гіпергенні мінерали, які генетично пов'язані з каолінітом. Слід зазначити, що підвищений вміст оксиду титану й заліза є характерним для первинних каолінів Глухівецько-Турбівського району в цілому [10]. У результаті виконаних досліджень встановлено, що власні мінеральні форми титану й заліза в збагаченому каоліні відсутні. Найімовірніша форма знаходження цих елементів тонкодисперсний домішок гідроксидів заліза й лейкоксену в каолініті. Вміст $\mathrm{Fe}_{2} \mathrm{O}_{3}$ практично не змінюється як за фракціями, так і за різновидами порід (табл. 3).

\section{Таблиця 3. Вміст оксидів титану і заліза в каоліновому концентраті в його гранулометричних фракціях за різновидами порід}

\begin{tabular}{|c|c|c|c|c|c|}
\hline \multirow{2}{*}{ К омпонент } & \multicolumn{5}{|c|}{ В міст у відсотках зафракціями } \\
\hline & К онцентрат & $50-10$ & $10-5$ & $5-2$ & $<2$ \\
\hline \multicolumn{6}{|c|}{ К аоліни за чудново-бердичівськими гранітами } \\
\hline $\mathrm{TiO}_{2}$ & 0,74 & 0,99 & 0,90 & 1,05 & 0,41 \\
\hline $\mathrm{Fe}_{2} \mathrm{O}_{3}$ & 0,25 & 0,21 & 0,26 & 0,25 & 0,27 \\
\hline В ихід каолінового концентрату & 100 & 19,8 & 24,6 & 15,4 & 40,2 \\
\hline \multicolumn{6}{|c|}{ К аоліни за апліт-пегматоїдними гранітами } \\
\hline $\mathrm{TiO}_{2}$ & 0,55 & 0,58 & 0,83 & 0,90 & 0,27 \\
\hline $\mathrm{Fe}_{2} \mathrm{O}_{3}$ & 0,19 & 0,20 & 0,18 & 0,18 & 0,16 \\
\hline В ихід каолінового концентрату & 100 & 25,4 & 6,0 & 22,5 & 48,1 \\
\hline \multicolumn{6}{|c|}{ К аоліни за гнейсами } \\
\hline $\mathrm{TiO}_{2}$ & 2,99 & 4,17 & 3,29 & 2,19 & 0,73 \\
\hline $\mathrm{Fe}_{2} \mathrm{O}_{3}$ & 0,22 & 0,22 & 0,23 & 0,22 & 0,24 \\
\hline В ихід каолінового концентрату & 100 & 23,2 & 47,9 & 15,7 & 13,2 \\
\hline
\end{tabular}

Проведений порівняльний аналіз за технологічними характеристиками каолінів Жежелівського та інших широко відомих родовищ району показав, що всі родовища $є$ близькими за показниками, що порівнювалися (табл. 4). Однак за якістю сировини Жежелівське родовище (за більшістю параметрів) не поступається (у деяких випадках навіть вища) первинним каолінам не тільки українських, але й багатьох інших родовищ, які успішно експлуатуються протягом тривалого часу.

Типовим для родовищ Глухівецько-Турбівського каолінового району важається наявність вертикальної зональності і присутність у розрізі трьох основних зон (знизу догори): зона початкового вилуговування і дезінтеграції (дресвяно-щебениста); зона часткового розкладу з переважним розвитком проміжних продуктів вивітрювання (каолініт-гідрослюдиста); зона повного розкладу первинних мінералів із заміною їх стійкими при даних умовах кінцевими продуктами вивітрювання (каолінітова) (див. рис. 1). 


\section{Таблиця 4. Порівняльна характеристика якості первинних каолінів}

\begin{tabular}{|c|c|c|c|c|}
\hline Показник & $\begin{array}{c}\text { Жежелівське } \\
\text { родовище }\end{array}$ & $\begin{array}{c}\text { Глухівецьке } \\
\text { родовище }\end{array}$ & $\begin{array}{c}\text { Великогадоминецьке } \\
\text { родовище }\end{array}$ & $\begin{array}{c}\text { Турбівське } \\
\text { родовище }\end{array}$ \\
\hline В ихід каолінового концентрату, \% & 64,8 & 63,8 & 59,7 & 64,1 \\
\hline Білизна, \% & 80,8 & 78,5 & 82,0 & 69,0 \\
\hline $\mathrm{Al}_{2} \mathrm{O}_{3} \%$ & 37,66 & 36,8 & 37,6 & $28,0-36,6$ \\
\hline $\mathrm{Fe}_{2} \mathrm{O}_{3}, \%$ & 0,46 & 0,59 & 0,46 & $06-30$ \\
\hline $\mathrm{TiO}_{2}, \%$ & 1,08 & 0,70 & 0,76 & 1,1 \\
\hline $\mathrm{SO}_{3}, \%$ & $0,01-0,17$ & $0,01-0,16$ & $0,02-0,07$ & $0,02-0,34$ \\
\hline Водорозчинних солей, \% & $0,038-0,072$ & $0,0075-0,38$ & & \\
\hline Природна вологість каоліну, \% & $18,5-20,5$ & 19,2 & 22,3 & \\
\hline Об'ємна маса, г/см & 1,95 & 2,0 & 1,94 & \\
\hline
\end{tabular}

Початкова зона розпочинається від зачеплених вивітрюванням і вивітрілих кристалічних порід до каолініт-гідрослюдистої зони. Їй властиве переважання фізичного вивітрювання над процесами хімічного перетворення. Породи цієї зони характеризуються підвищеною мікротріщинуватістю, вони ослаблені, легко розділяються на окремі фрагменти і $€$ частково каолінізованою складовою материнських порід. Мінеральний склад зони близький до складу материнських порід, а його зміни виражаються у гідратації первинних і утворенні вторинних мінералів (польові шпати змінені, по периферії частково заміщуються каолінітом, біотит-гідробіотитом і хлоритом).

У проміжній каолініт-гідрослюдистій зоні переважають процеси хімічного вивітрювання; мінеральний склад її різноманітніший і відзначається як наявністю реліктових мінералів (кварцу, калієвого польового шпату, рудних і акцесорних мінералів), так і присутністю глинистогідрослюдистих гіпергенних новоутвореь (гідрослюди, хлориту, монтморилоніту, частково каолініту).

Остання каолінітова зона складає верхню частину КВ і характеризується практично повним заміщенням основних породоутворюючих мінералів глинистими компонентами. Першочергову роль при цьому відіграють складні процеси хімічного вивітрювання (розчинення та гідроліз), в результаті яких відбувається розклад основних породоутворюючих мінералів з повним або частковим руйнуванням кристалічної ґратки і заміна їх каолінітом. Отже, головним мінералом КВ, і каолінітової зони зокрема, є каолініт; поряд з ним присутні кварц, акцесорні та рудні мінерали, а в нижній частині зони - релікти зерен польових шпатів. За цією ознакою в каолінітовій зоні виділяються дві підзони: 1) підзона первинних нормальних каолінів, що характеризуються повним розкладом алюмосилікатів; 2) підзона лужних каолінів з підвищеним вмістом реліктових зерен не розкладеного польового шпату.

Проведені дослідження показали, що у межах Глухівецько-Турбівського каолінового району у цілому з його відомими родовищами найоптимальнішим субстратом високоякісних покладів первинного каоліну $є$ тіла пегматитів та апліт-пегматоїдних гранітів. Загалом, невелика кількість забарвлених мінералів або ще краще іх повна відсутність, наявність світлої слюди, невисокі вмісти заліза й титану у вихідних породах - все це складає низку необхідних умов для встановлення цінних каолінових родовищ. I навпаки, каоліни, утворені за породами із значним вмістом забарвлених мінералів, наприклад за біотитовими гнейсами, відрізняються невисокою якістю, хоча вихід збагаченого каоліну в цьому випадку максимальний.

Мінералогічні та петрографічні дослідження первинних каолінів показали, що у профілі КВ Глухівецько-Турбівського каолінового району головним глинистим мінералом $€$ каолініт. Він утворюється в зоні дезінтеграції та початкового розкладу кристалічних порід, поступово заміщує всі мінеральні утворення, за винятком кварцу та акцесоріїв. Встановлено, що для всіх родовищ характерним є розвиток класичного каолінового профілю КВ з добре вираженою зональністю.

Виділені на підставі досліджень три основних різновиди первинних каолінів практично неможливо відокремити в конкретні площі за їх розвитком, що зумовлено наявністю різноманітних кристалічних порід, складністю їх взаємопереходів та структурно-текстурними особливостями. 


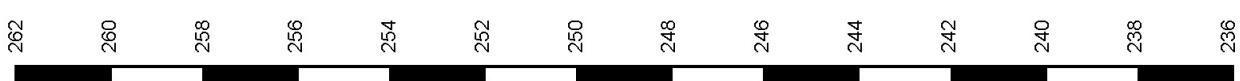

인

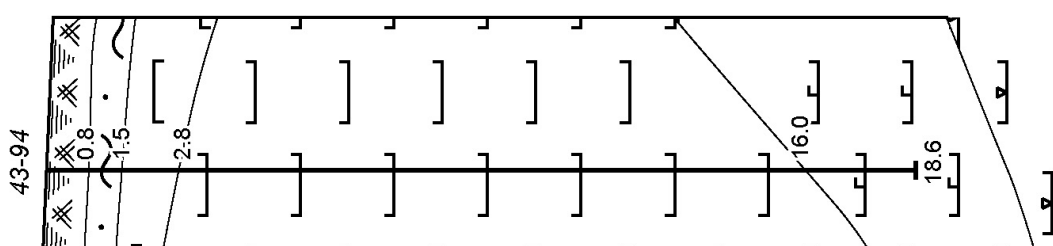

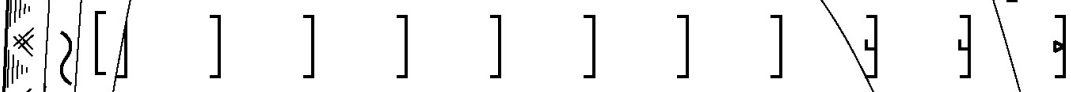

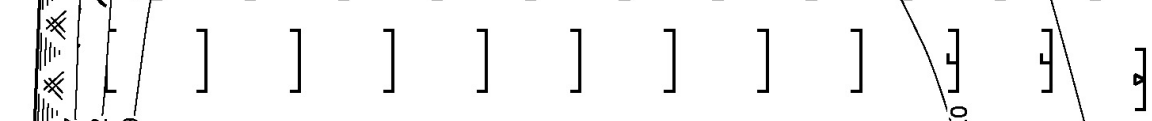

\丶丶

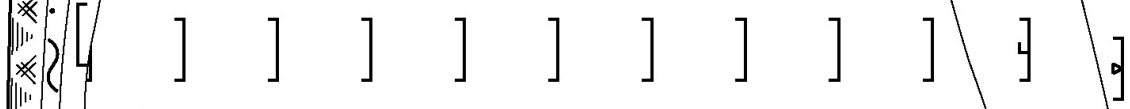

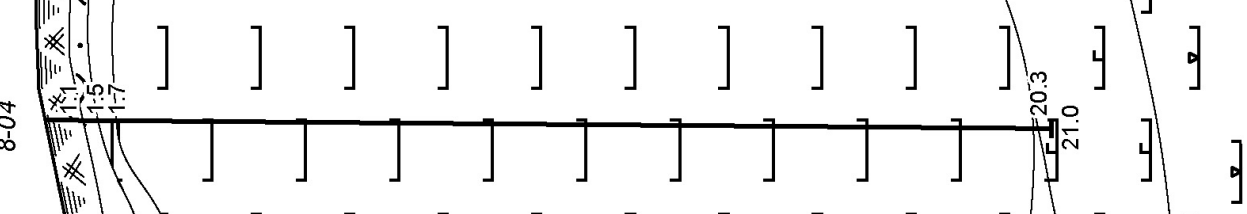

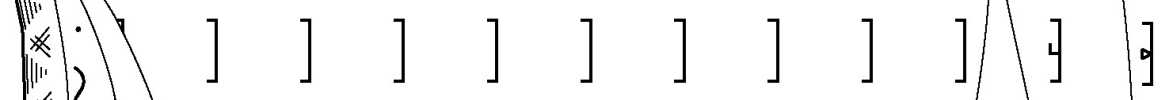

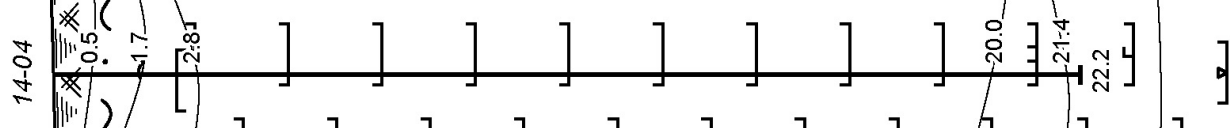

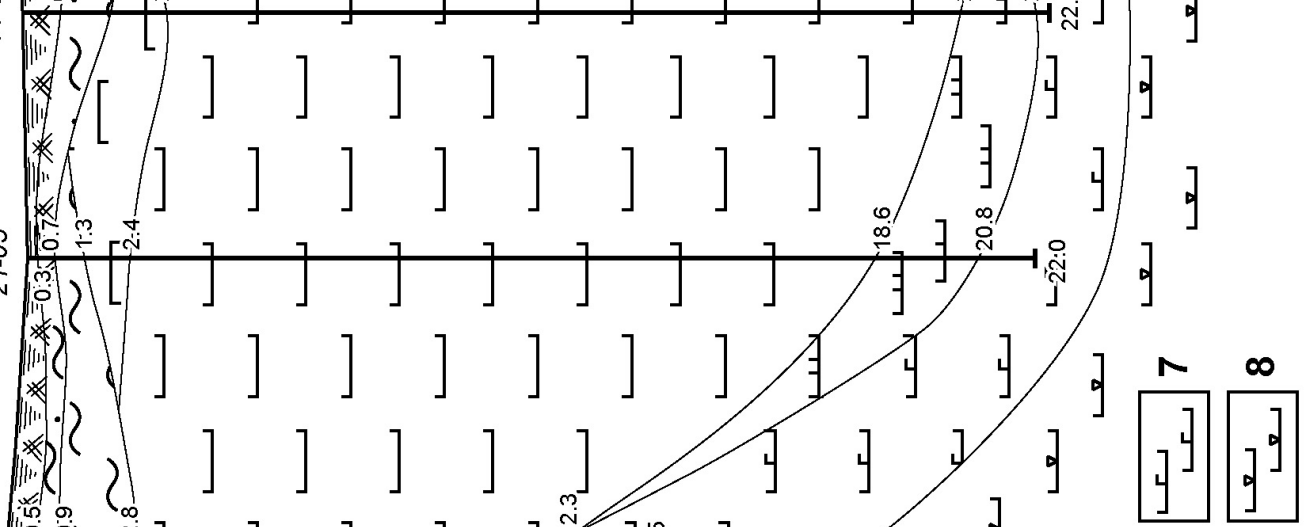

응 온

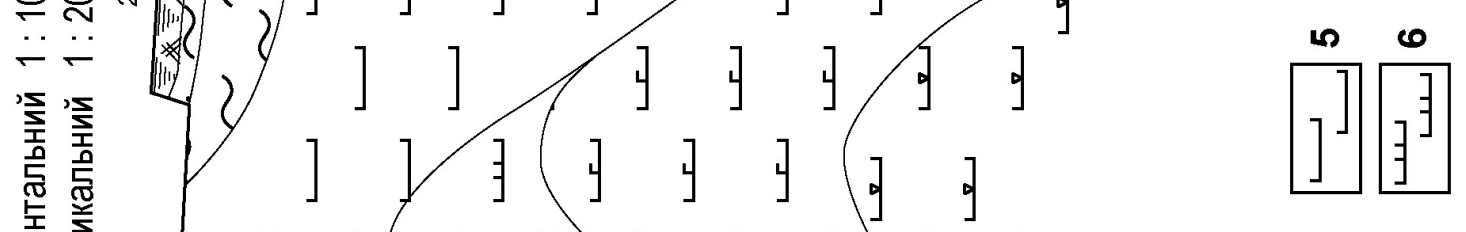

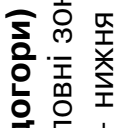

은

产

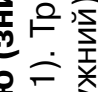

는

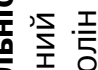

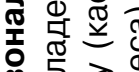

:

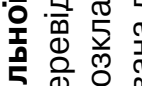

ॠ๐

돈인

迥 융

오 1 츤

竞

$+\frac{\pi}{T}: \overline{3}$

혿원

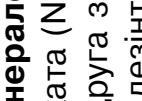

品 0

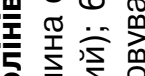

๙

๓

퐇응으은

응 次

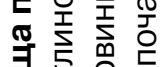

离

ㄴ.

웅인

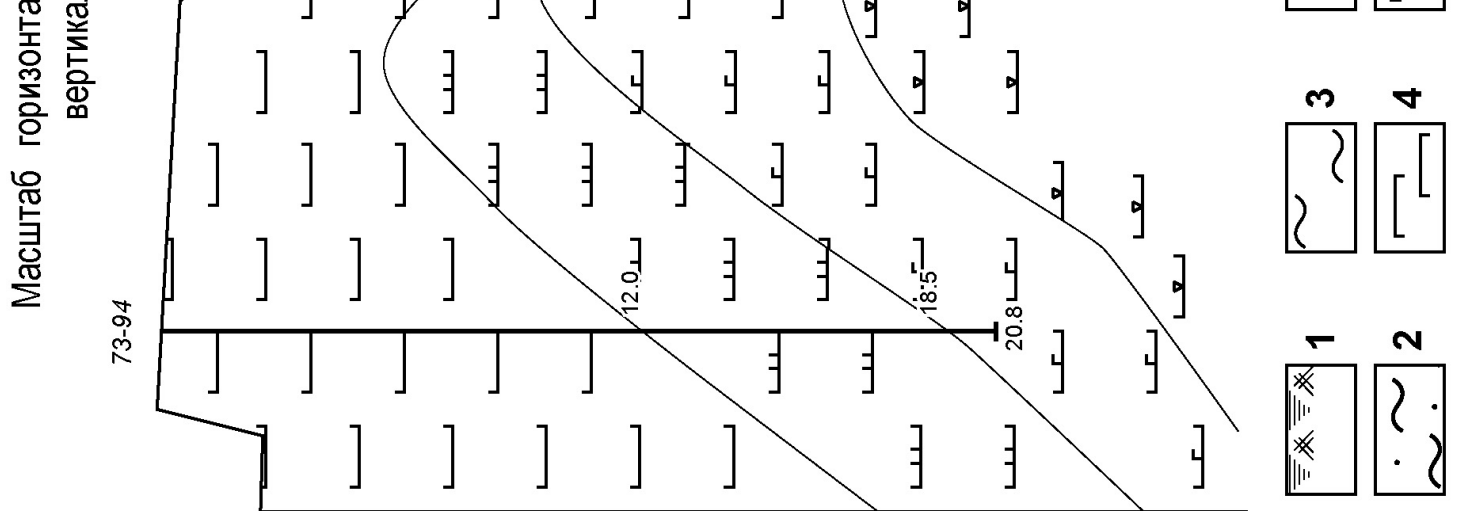

잉 离

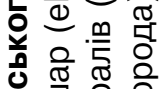

블웡음

可突焉

핯 夌 동 돈

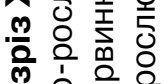

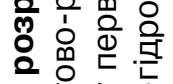

点高空高 


\section{Г.О. СЛЮСАРЕНКО}

1. Венедиктов В.М. Полициклическое развитие гранулитовой фации. - Киев: Наук. думка, 1986.

2. Гурський Д.С., Єсипчук К.Ю., Калінін В.І. та ін. Металічні і неметалічні корисні копалини. Т. ІІ. Неметалічні корисні копалини. - К.-Львів: Центр Європи, 2006.

3. Звіт про експлуатаційну розвідку Жежелівського родовища каолінів за результатами геологорозвідувальних робіт, виконаних у 2004-2005 рр. - Вінниця, 2005.

4. Крутиховская 3.А. и др. Магнитная модель и структура земной коры Украинского щита. - Киев: Наук. думка, 1982.

5. Лесная И.М. Геохронология чарнокитоидов Побужья. - Киев: Наук. думка, 1988.

6. Наливкина Э.Б. Офиолитовые ассоциации раннего докембрия. - М.: Недра, 1977.

7. Половинкина Ю.И. Стратиграфия и роль ультраметаморфизма в Украинском кристаллическом массиве, проблемы геологии докембрия. - К.: Наук. думка, 1971.

Institute of Geological Sciences NAS Ukraine, Kyiv, Ukraine Інститут геологічних наук НАН України, м. Київ, Україна
8. Рябенко В.А. Текстура глибокометаморфізованих порід докембрію України. - Київ: Наукова думка, 1976.

9. Слензак О.И. Чарнокиты Приднестровья и некоторые общие вопросы петрологии. - Киев: Изд-во АН СССР, 1961.

10. Ткачук Л.Г., Сонкин Л.С. Каолины Глуховецко-Турбовского района Украинского щита и перспективы их использования. - Киев: Наук. думка, 1981.

11. Шевченко В.І., Щербак Д.М., Загоруйко Ю.Т. Геологоекономічні особливості Жежелівського родовища каоліну // Вісник КНУ. Геологія - 2000. - №18.

12. Щербак Н.П. Петрология и геохронология докембрия западной части Украинского щита. - Киев: Наук. думка, 1975.

13. Щербак Д.М., Приходько В.К., Шевченко В. І. Особливості якісного складу первинних каолінів Жежелівського родовища // Там же. 2002 - № 22.

14. Эльянов М.Д. Формация коры выветривания кристаллических пород Украинского щита, Кн. І, Кн. ІІ. Днепропетровск, 1993. 